\title{
Water potential and time of Pyrenophora tritici-repentis inoculation in wheat seeds
}

\author{
Potencial hídrico e duração da inoculação com \\ Pyrenophora tritici-repentis em sementes de trigo
}

\author{
Victória Vieira Bertagnolli1*; Carolina Cardoso Deuner ${ }^{2}$; \\ Patrícia Frizon ${ }^{3}$; Valéria Cecília Ghissi ${ }^{3}$
}

\begin{abstract}
Wheat seeds infected with Pyrenophora tritici-repentis, the causal agent of tan spot, are partially responsible for outbreaks caused by this pathogen. Seed lots with a high incidence of $P$. tritici-repentis must be rapidly acquired for transmission and pathogen-control studies. Therefore, the aim of this study was to determine whether changes in water potential of culture medium and variations in inoculation time might favor the infection of wheat seeds by $P$. tritici-repentis without compromising seed viability. Colonies of $P$. tritici-repentis were grown on potato-dextrose-agar (PDA) culture medium, adjusted to a water potential of $-0.36 \mathrm{MPa}$, under water stress induced by mannitol at potentials of $-0.4,-0.6,-0.8$, -1.0 , and $-1.2 \mathrm{MPa}$. Analyses were carried out to determine mycelial growth index and seed exposure time to the culture medium to start germination as a function of water potential. Afterwards, wheat seeds were placed in contact with colonies of $P$. tritici-repentis for 24, 48, and 72 hours at potentials of $-0.4,-0.6,-0.8,-1.0$, and $-1.2 \mathrm{MPa}$. The experiment was arranged in a completely randomized design, in a factorial scheme (water potential $\times$ inoculation time). Rates of germination, seedling emergence in soil, and seed infection were assessed. Mycelial growth was stimulated at lower water potentials, which germinated faster. A 24-hour inoculation time and a $-0.4 \mathrm{MPa}$ water potential were efficient to infect wheat seeds with $P$. tritici-repentis, without hindering seedling germination and emergence under laboratory conditions.
\end{abstract}

Key words: Drechslera tritici-repentis. Tan spot of wheat. Mannitol. Triticum aestivum.

\section{Resumo}

Sementes de trigo infectadas com Pyrenophora tritici-repentis, agente causal da mancha-amarela da folha, respondem em parte pelas epidemias causadas por este patógeno. A obtenção rápida de lotes de sementes com alta incidência de $P$. tritici-repentis é fundamental para estudos de transmissão e controle. Sendo assim, o objetivo deste trabalho foi verificar se alterações no potencial hídrico do meio de cultura e variações na duração da inoculação podem favorecer a infecção de sementes de trigo por $P$. triticirepentis, sem comprometer a viabilidade destas sementes. Colônias do patógeno foram cultivadas sobre meio de cultura batata-dextrose-ágar (BDA) básico, no potencial hídrico de - $0,36 \mathrm{MPa}$, e no meio BDA com restrição hídrica, causada pela adição de manitol, nos potenciais hídricos de $-0,4,-0,6,-0,8,-1,0$ e -1,2 MPa. Foram realizadas análises para determinar o índice de crescimento micelial do fungo e o tempo de exposição das sementes ao meio de cultura para o início do processo germinativo em função

\footnotetext{
${ }^{1}$ M.e em Agronomia, Discente de Doutorado, Universidade de Passo Fundo, UPF, Passo Fundo, RS, Brasil. E-mail: victoriabertagnolli@gmail.com

${ }^{2}$ Dr $^{\mathrm{a}}$. em Agronomia, Prof $f^{\mathrm{a}}$ Adjunta, UPF, Passo Fundo, RS, Brasil. E-mail: carolinadeuner@upf.br

${ }^{3}$ Mestres em Agronomia, Discentes de Doutorado, UPF, Passo Fundo, RS, Brasil. E-mail: patriciafrizon@gmail.com; val_ghissi@ hotmail.com

* Author for correspondence
} 
dos potenciais hídricos. Posteriormente, sementes de trigo foram colocadas em contato com as colônias de $P$. tritici-repentis durante 24,48 e 72 horas nos potenciais hídricos de $-0,4,-0,6,-0,8,-1,0$ e $-1,2$ $\mathrm{MPa}$, em esquema fatorial (potenciais hídricos x duração da inoculação) e delineamento inteiramente casualizado. Foram avaliadas as taxas de germinação, de emergência de plântulas em solo e de infecção de sementes. Houve estímulo ao crescimento micelial nos menores potenciais hídricos, sendo que nesses potenciais, o tempo para início de germinação é maior. A duração da inoculação de 24 horas e o uso de restrição hídrica com potencial de $-0,4 \mathrm{MPa}$ foram eficientes para infectar sementes de trigo com $P$. tritici-repentis, sem prejudicar a germinação e a emergência de plântulas em condições de laboratório.

Palavras-chave: Drechslera tritici-repentis. Mancha-amarela. Manitol. Triticum aestivum.

\section{Introduction}

The fungus Pyrenophora tritici-repentis (Died.) Drechsler, the anamorphic form of Drechslera tritici-repentis (Died.) Shoemaker, is the causal agent of the tan spot (SANTANA et al., 2008), a major foliar blight disease in wheat-growing areas worldwide (PATEL et al., 2011). Seeds and crop residues infected are important epidemiological factors of this disease, serving as a source of primary inoculum (SCHILDER; BERGSTROM, 1995). Studies on factors promoting inoculation of P. tritici-repentis in wheat seeds are essential since they enable a rapid acquisition of high-incidence seed lots, for further studies. Knowing the specific relationships between pathogens and hosts is important to encourage research and information regarding transmission and epidemiological behavior of the diseases, pathogen control, and cultivar resistance.

Water stress is used to control or inhibit seed germination under different circumstances such as in health tests on paper substrate (CELANO et al., 2012) and potato dextrose agar medium (PDA) (GARCIA JÚNIOR et al., 2008), and in fungal inoculation tests (FARIAS et al., 2010), besides simulating water deficit (GIROTTO et al., 2012), osmotic and matric conditioning (QUEIROGA et al., 2011) for crops of interest. A water restriction condition can be obtained by adjusting water potential with osmotically active solutes, with the most common being mannitol, polyethylene glycol, maltose (GIROTTO et al., 2012), $\mathrm{KCl}, \mathrm{NaCl}$, sucrose (GARCIA JÚNIOR et al., 2008), or $\mathrm{CaCl}_{2}$ (MACHADO NETO et al., 2006). Thus, bipolar water molecules are attracted and retained by these solutes, inducing a decrease in water activity (FERREIRA, 1988).

Water restriction techniques for fungal inoculation of seeds are based on seed-inoculum using a culture medium with known water potential. This stage should last long enough to favor infection, without seed germination midway through the inoculation. Therefore, the water potential of medium must be adjusted so that all germination preparatory processes can occur without inducing cell elongation and radicle extension (HEYDECKER et al., 1975). In this sense, several studies have succeeded in using water restriction for inoculation of phytopathogenic fungi in seeds such as $F$. oxysporum f. sp. vasinfectum (SOUZA et al., 2008), Colletotrichum gossypii, C. gossypii var. cephalosporioides, Botryodiplodia theobromae (MACHADO et al., 2004) in cotton seeds, Diplodia maydis, Cephalosporium acremonium, and Fusarium moniliforme in corn seeds (MACHADO et al., 2001a).

Selection of a proper water potential by means of solutes, as well as the time required for seed exposure to inoculum, are essential for inoculation to succeed. Therefore, this study aimed to determine whether changes in water potential of culture medium and variations in inoculation time might favor infection of wheat seeds by $P$. tritici-repentis without compromising seed viability for further transmission studies on the wheat-P. tritici-repentis pathosystem. 


\section{Material and Methods}

Basic seeds of wheat cultivar TBIO Sintonia (Biotrigo Genética) were used in the experiment. They were obtained from the propagation of genetic seeds to guarantee genetic identity and varietal purity of the cultivar (FAEP, 2006). The seeds were harvested in the 2013 crop-growing season, being selected after preliminary tests of health, germination, and vigor. Initially, these seeds were subjected to surface disinfestation with $1 \%$ sodium hypochlorite for two minutes. P. tritici-repentis inoculum was kindly provided by the mycology collection of the Laboratory of Phytopathology, University of Passo Fundo - RS, Brazil. The inoculum was isolated from wheat leaves of cultivar BRS Guamirim, which was developed by the Brazilian Agricultural Research Corporation (EMBRAPA), being collected in the city of Coxilha - RS (Brazil). The inocula were refrigerated at nearly $7{ }^{\circ} \mathrm{C}$ on potato dextrose agar (PDA) culture medium, after monosporic isolation.

Preparation of culture medium at different water potentials

Mannitol was added to the PDA basic culture medium (39 g PDA Merck $\mathrm{L}^{-1}$ distilled water) to obtain five water potentials: $-0.4,-0.6,-0.8$, -1.0 , and -1.2 $\mathrm{MPa}$. An additional water potential of $-0.36 \mathrm{MPa}$, known to be the water potential of the basic PDA medium, i.e. without adding mannitol (WEARING; BURGUESS, 1979), was used exclusively for tests of mycelial growth index (MGI) and time to start seed germination process. Amounts of 1.8, 8.8, 15.7, 22.5, and $29.1 \mathrm{~g}$ mannitol were added in $500 \mathrm{~mL}$ PDA medium before autoclaving to reach water potentials of $-0.4,-0.6$, $-0.8,-1.0$, and $-1.2 \mathrm{MPa}$, respectively; these values were calculated by the software SPPM (MICHEL; RADCLIFFE, 1995). The temperature used in the calculations was $25^{\circ} \mathrm{C}$. After sterilization, $15 \mathrm{~mL}$ of basic PDA medium and those osmotically modified with mannitol were poured into 9-cm diameter plastic Petri dishes in a laminar flow chamber, according to the treatment.

Mycelial growth of $P$. tritici-repentis at different water potentials

Discs of $4.2 \mathrm{~mm}$ diameter were taken from the medial portion of 10-day incubation pure culture of $P$. tritici-repentis, being transferred to the center of each Petri dish with PDA. Ten replications were used for each water potential, being the dishes randomly distributed in a growth chamber with 12-hour photoperiod at $25{ }^{\circ} \mathrm{C}$. Assessments were performed daily by measuring the colony diameter with a digital caliper, until the mycelium reached the edge of the dish. The MGI was determined by the formula: $\mathrm{MGI}=\mathrm{C}_{1}+\mathrm{C}_{2}+\ldots+\mathrm{C}_{\mathrm{n}} / \mathrm{N}_{1}+\mathrm{N}_{2}+\ldots$ $+\mathrm{N}_{\mathrm{n}}$ (OLIVEIRA, 1991), where $\mathrm{C}$ is the mycelial growth of colonies at each assessment and $\mathrm{N}$ is the number of running days at each assessment, after transferring the mycelium discs.

Exposure time of wheat seeds to P. tritici-repentis at different water potentials before the start of germination

Ten grams of wheat seeds was added per Petri dish with grown colony of $P$. tritici-repentis on culture medium with different water potentials, in five replications. Assessments were carried out every 12 hours. The time (in hours), within which a 4-mm length radicle appeared in the first seed, was counted at each water potential.

\section{Seed-inoculum contact}

Ten grams of wheat seeds were added per Petri dish with grown colony of $P$. tritici-repentis on culture medium with different water potentials, being gently pressed against the medium to increase seed-inoculum contact surface. After 24, 48, and 72 hours, seeds were removed from the medium and placed on filter papers to dry under laboratory 
conditions for 24 hours. Afterwards, these seeds were assessed for paper substrate germination, soil emergence, and seed health on PDA medium.

Germination of wheat seeds inoculated with $P$. tritici-repentis

Four replications with 50 seeds were used per treatment (five water potentials $\times$ three inoculation lag times), in addition to a control treatment (noninoculated seeds). The seeds were conditioned in discs of filter paper moistened with distilled water, using an amount of water 2.5 times the paperweight; these discs were then taken to a germinator at $20^{\circ} \mathrm{C}$. On the seventh day of incubation, the percentage of normally developed seedlings was computed.

Emergence of wheat seedlings inoculated with $P$. tritici-repentis

Inoculated seeds, submitted to different treatments (five water potentials $\times$ three inoculation lag times), were sown in plastic trays filled with a mixture of soil and sand mixed (2:1) at a depth of $1.5 \mathrm{~cm}$. Four replicates with 50 seeds were used per treatment, in addition to a control treatment (noninoculated seeds). Trays were randomly distributed in a growth chamber at $18 \pm 2{ }^{\circ} \mathrm{C}$ and 12-hour photoperiod. The substrate was watered every two days with the same water volume for each tray. Fourteen days after sowing, the percentage of normal emerged seedlings was counted.

\section{Health of wheat seeds inoculated with P. tritici- repentis}

Seed health was assessed by using the plating method on PDA (BRASIL, 2009) using four replications with 50 seeds per treatment (five water potentials $\times$ three inoculation lag times), in addition to a control treatment (non-inoculated seeds). The seeds were disinfested with $1 \%$ sodium hypochlorite solution for two minutes and washed with sterile distilled water. The dishes were maintained in an incubation chamber at $25{ }^{\circ} \mathrm{C}$ and 12-hour photoperiod. Seven days after plating, colony general characteristics were assessed by the observation of white aerial mycelium and darkolive creeping mycelium (MEHTA, 1993; WIESE, 1987). In addition, when present, conidia, and conidiophores of $P$. tritici-repentis were observed through a stereoscopic microscope, comparing them with those described in the literature (BARNETT; HUNTER, 1972). Results were given as a percentage of infected seeds in relation to the total number inoculated.

\section{Statistical analysis}

All the experiments were completely random designs. Data were analyzed using Assistat software (SILVA; AZEVEDO, 2002). The MGI data and seed germination starting time underwent analysis of variance (ANOVA) and regression analysis. Percentage data were arcsine square root transformed prior to ANOVA, performing a twofactorial analysis of variance (five water potentials $\times$ three inoculation times), in addition to a control treatment. Tukey's test was used as a means comparison test for each factor, and a Dunnett's test was performed to compare the treatments with the control.

\section{Results and Discussion}

Mycelial growth of P. tritici-repentis

A significant linear effect was observed for MGI as a function of the studied water potentials $(\mathrm{P}<0.01)$ (Figure 1). Decreasing water potentials of PDA medium with mannitol had no inhibitory effect on pathogen growth. Comparatively, Carvalho et al. (2001) observed that colonies of C. lindemuthianum presented a higher average diameter in an osmotically modified PDA medium with mannitol up to a water restriction level of $-0.61 \mathrm{MPa}$. Likewise, Alam et al. (1996) observed that culture media with 
osmotic concentrations between -0.3 and $-1.0 \mathrm{MPa}$ better osmotic adjustment of fungal cells, providing stimulated the mycelial growth of Botrytis cinerea a greater turgor for cell expansion and, therefore, Pers. and Alternaria alternata (Fr) Keissler. It might a better stimulus to mycelial growth (DUNIWAY, have occurred due to a higher solute absorption and 1979).

Figure 1. Mycelial growth index (MGI) of Pyrenophora tritici-repentis as a function of different water potentials of potato dextrose agar (PDA) culture medium. UPF, Passo Fundo, RS, Brazil, 2015.

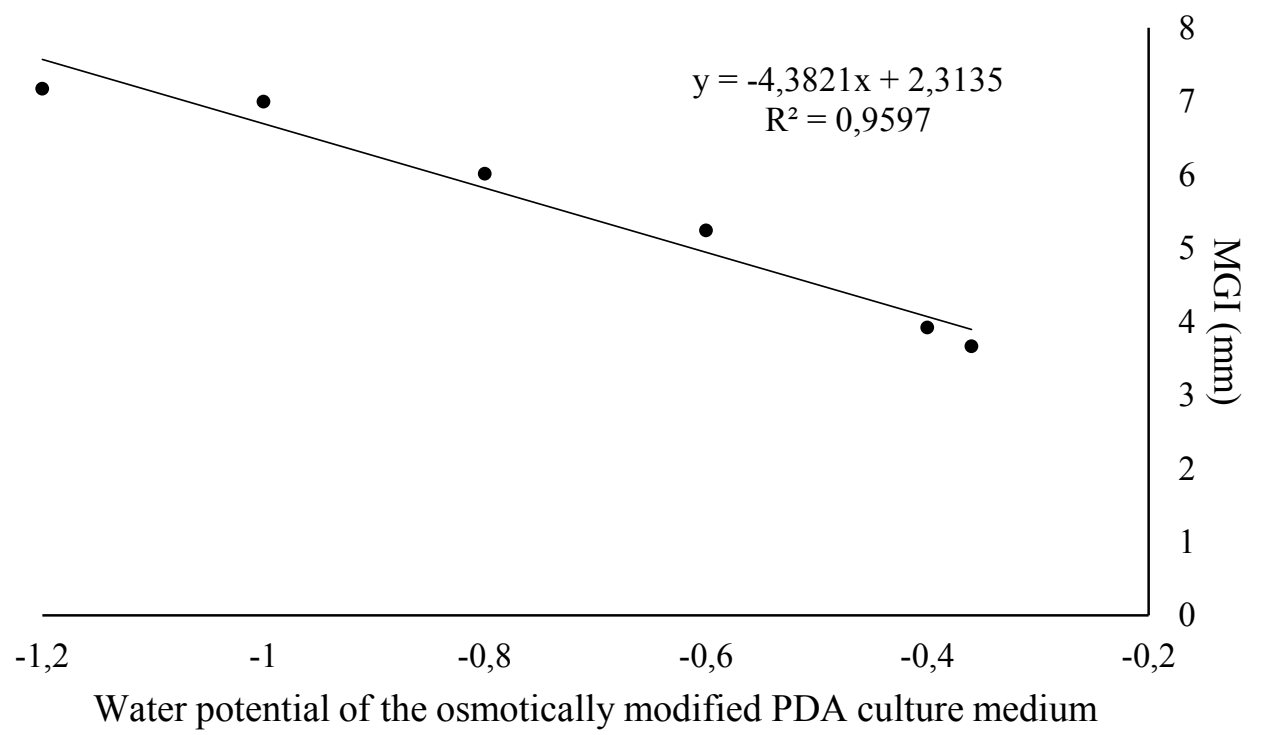

$(\mathrm{MPa})$

Figure 2. Germination starting time of wheat seeds (cultivar TBIO Sintonia) as a function of different water potentials of potato dextrose agar (PDA) culture medium. UPF, Passo Fundo, RS, Brazil, 2015.

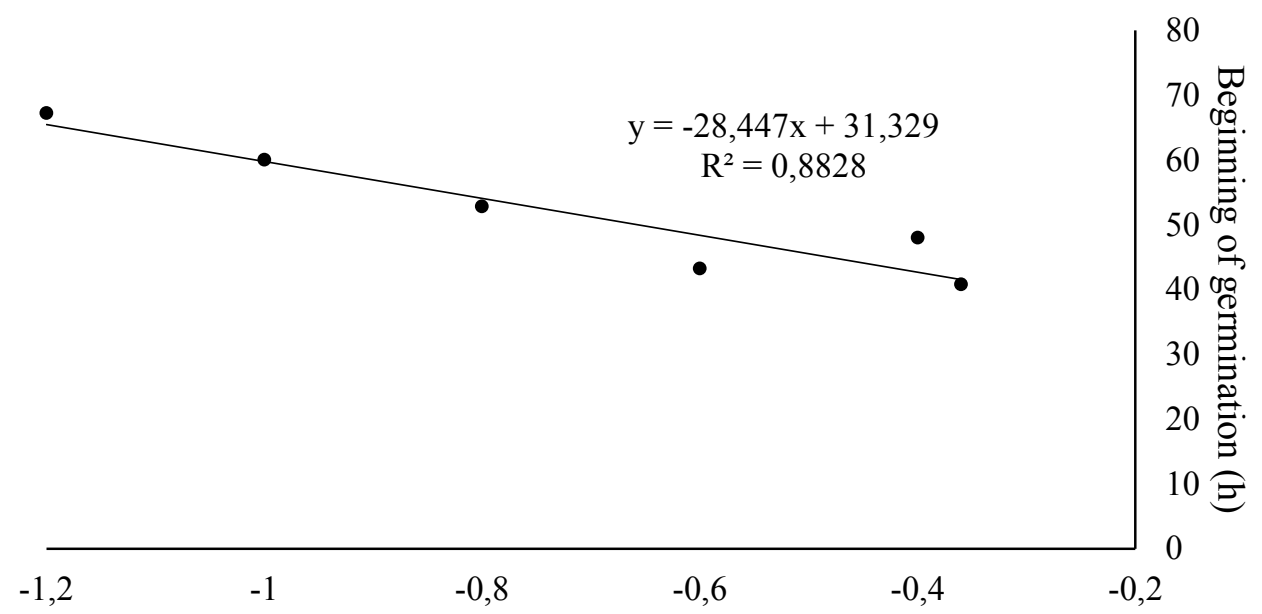

Water potential of the osmotically modified PDA culture medium

$(\mathrm{MPa})$ 
Exposure time of wheat seeds to P. tritici-repentis at different water potentials

The time to start seed germination presented a significant linear response to the studied water potentials $(\mathrm{P}<0.01) \quad$ (Figure 2). Lower water potentials promoted longer times to germination and hence a prolonged exposure to the pathogen. The minimum and maximum estimated time lags for the first seed germination were 41.6 and $65.5 \mathrm{~h}$, both at the lowest and highest assessed water potential (-0.36 and $-1.2 \mathrm{MPa}$, respectively). Although the decreasing potentials delayed the radicle emission, it occurred in all the tests. Solutes such as mannitol reduce the free energy of water since they cause disorder in the system (TAIZ; ZEIGER, 2009). Thus, the higher the amount of solute in the medium is, the lower the availability of water for seed germination. This statement justifies the delay in radicle emission at lower water potentials.
Germination of wheat seeds inoculated with $P$. tritici-repentis

Table 1 shows a significant interaction between water potentials and inoculation times. Germination had no effect of any water potential or inoculation time. At 24 hours of inoculation, germination percentage at $-1.2 \mathrm{MPa}$ was statistically the lowest, but not differing from $-1.0 \mathrm{MPa}$. This might have occurred because, at this potential, seeds were deprived of water from the medium. At $-1.2 \mathrm{MPa}$, germination was favored at an inoculation time of 48 hours, but not differing from that of 72 hours. At 48 hours of incubation, there was no statistical difference between the studied water potentials. On the other side, at 72 hours of incubation, germination at $-0.4 \mathrm{MPa}$ was statistically lower if compared to the others. Such an outcome might have been a consequence either of the higher water content absorbed by seeds or of the earlier germination start, as observed in this study, leading to a major loss in seed reserves.

Table 1. Germination percentage of wheat seeds (cultivar TBIO Sintonia) on filter paper after inoculation with Pyrenophora tritici-repentis, at different water potentials of culture medium and contact time with the pathogen. UPF, Passo Fundo, RS, Brazil, 2015.

\begin{tabular}{crlrl}
\hline \multirow{2}{*}{ Water potential (MPa) } & \multicolumn{9}{c}{ Inoculation time (h) } \\
\cline { 2 - 5 } & 24 & 48 & 72 \\
\hline-0.4 & $92 \mathrm{aA}^{1}$ & $93 \mathrm{aA}$ & $39^{*}$ & $\mathrm{bB}$ \\
-0.6 & $95 \mathrm{aA}$ & $94 \mathrm{aA}$ & 85 & $\mathrm{aA}$ \\
-0.8 & $95 \mathrm{aA}$ & $93 \mathrm{aA}$ & $77^{*}$ & $\mathrm{aB}$ \\
-1.0 & $80 \mathrm{abA}$ & $91 \mathrm{aA}$ & $88 \mathrm{aA}$ \\
-1.2 & $77^{*} \mathrm{bB}$ & $85 \mathrm{aAB}$ \\
\hline CV $(\%)$ & 8.33 & & \\
\hline
\end{tabular}

${ }^{1}$ Means followed by the same letter, lowercase on the column and uppercase on the row, do not differ from each other by the Tukey's test at 5\% probability. *Value differs from the control treatment (non-inoculated) by the Dunnett's test at 5\% probability, with $93 \%$ germination.

Emergence of wheat seedlings inoculated with $P$. tritici-repentis

Table 2 displays a significant interaction between water potentials and inoculation times for the emergence of normal seedlings. After 24 hours, all studied water potentials provided an emergence of normal seedlings statistically higher when compared to 48 and 72 hours, except for $-0.8 \mathrm{MPa}$ that was statistically equal at both 24 and 48 hours, and $-1.2 \mathrm{MPa}$ that was statistically higher at 48 hours. Similarly, Barrocas et al. (2014) demonstrated that longer times of contact between seeds and media with low water restriction, even in the absence of pathogens, compromised cotton 
seedling emergence. In this sense, the reduced number of normal seedlings emerged after 72 hours of incubation might have been related to the inability of water potential in inhibiting the beginning of germination after 65 hours.

At the inoculation time of 24 hours, a similar behavior to the germination test was observed for seedling emergence in soil with water potential of $-1.2 \mathrm{MPa}$, statistically lower when compared to the other water potentials. At 48 and 72 hours of incubation, the water potential of $-0.4 \mathrm{MPa}$ provided an emergence of normal seedlings statistically lower when compared to the other water potentials.

Table 2. Emergence percentage of wheat seedlings (cultivar TBIO Sintonia) in soil substrate and growth chamber after inoculation with Pyrenophora tritici-repentis, at different water potentials of culture medium and contact time with the pathogen. UPF, Passo Fundo, RS, Brazil, 2015.

\begin{tabular}{|c|c|c|c|c|}
\hline \multirow{2}{*}{ Water potential $(\mathrm{MPa})$} & \multicolumn{4}{|c|}{ Inoculation time $(\mathrm{h})$} \\
\hline & 24 & 48 & 72 & \\
\hline-0.4 & $89 \mathrm{aA}^{1}$ & $49 * \quad \mathrm{cB}$ & $19 *$ & $\mathrm{bC}$ \\
\hline-0.6 & 88 aA & $74 *$ bB & $54 *$ & $\mathrm{aC}$ \\
\hline-0.8 & 84 aA & 89 aA & $54 *$ & $\mathrm{aB}$ \\
\hline-1.0 & 82 aA & $68 * \mathrm{bB}$ & $59 *$ & $\mathrm{aB}$ \\
\hline-1.2 & $71 * \quad b B$ & 85 aA & $53 *$ & $\mathrm{aC}$ \\
\hline CV $(\%)$ & 6.40 & & & \\
\hline
\end{tabular}

${ }^{1}$ Means followed by the same letter, lowercase on the column and uppercase on the row, do not differ from each other by the Tukey's test at 5\% probability. *Value differs from the control treatment (non-inoculated) by the Dunnett's test at 5\% probability, with $90 \%$ germination.

Health of wheat seeds inoculated with P. triticirepentis

Table 3 demonstrates a significant interaction between water potentials and inoculation time. All treatments differed statistically from the noninoculated (10\% infected seeds). It shows that the water restriction technique for infection studies with $P$. tritici-repentis is efficient at all the tested water potentials and inoculation times, varying from 49 to $82 \%$. Fungus infection was higher after 24 hours of inoculation and at $-0.4 \mathrm{MPa}$, after 48 hours at $-0.8 \mathrm{MPa}$, and after 72 hours at $-0.6 \mathrm{MPa}$. In short, 24 hours proved to be long enough for $P$. tritici-repentis infection, penetrating easily through the protective tissues of wheat seeds.
Farias et al. (2010) found similar results studying wheat seeds at different water potentials and inoculation times, noting that infection by $B$. sorokiniana was induced with an average efficiency of 53 to $92 \%$. Several other studies have shown that infection efficiency depends on the pathogen species. In this sense, Diplodia maydis required 120 hours in contact with corn seeds to cause infection, contrasting with $F$. moniliforme, which presented a high incidence from 48 hours of exposure (MACHADO et al., 2001b), as well as Phomopsis sojae, Sclerotinia sclerotiorum, and C. truncatum in soybean (MACHADO et al., 2001a). 
Table 3. Percentage of infected wheat seeds (cultivar TBIO Sintonia) on potato dextrose agar (PDA) medium after inoculation with Pyrenophora tritici-repentis, at different water potentials of culture medium and contact time with the pathogen. UPF, Passo Fundo, RS, Brazil, 2015.

\begin{tabular}{|c|c|c|c|}
\hline \multirow{2}{*}{ Water potential (MPa) } & \multicolumn{3}{|c|}{ Inoculation time $(\mathrm{h})$} \\
\hline & 24 & 48 & 72 \\
\hline-0.4 & $82 * \mathrm{aA}^{1}$ & $67 *$ abAB & $59 *$ bB \\
\hline-0.6 & $73 *$ abA & $71 * \quad a b A$ & $80 *$ aA \\
\hline-0.8 & $58 *$ bAB & $74 *$ aA & $56^{*}$ bB \\
\hline-1.0 & $59 * \mathrm{bA}$ & $60 * \quad \mathrm{abA}$ & $53 *$ bA \\
\hline-1.2 & $64 * \quad a b A$ & $49 * \mathrm{bA}$ & $55^{*} \mathrm{bA}$ \\
\hline
\end{tabular}

${ }^{1}$ Means followed by the same letter, lowercase on the column and uppercase on the row, do not differ from each other by the Tukey's test at 5\% probability. *Value differs from the control treatment (non-inoculated) by the Dunnett's test at 5\% probability, with $10 \%$ infected seeds.

In summary, a culture medium with a water potential of $-0.4 \mathrm{MPa}$ and a inoculation time of 24 hours are efficient to infect wheat seeds with $P$. triticirepentis, maintaining the percentage of germination and emergence of seedlings statistically equal to a non-inoculated treatment (control), justifying the use of water restriction for inoculating wheat seeds with $P$. tritici-repentis.

\section{Acknowledgements}

The authors thank the Coordination for the Improvement of Higher Education Personnel (CAPES) and the University of Passo Fundo (UPF).

\section{References}

ALAM, S.; JOYCE, D.; WEARING, A. Effects of equilibrium relative humidity on in vitro growth of Botrytis cinerea and Alternaria alternata. Australian Journal of Experimental Agriculture, East Melbourne, v. 36, n. 3, p. 383-388, jun. 1996. Available at: <http:// www.publish.csiro.au/an/EA9960269>. Accessed at: 29 nov. 2016.

BARNETT, H. L.; HUNTER, B. B. Illustred fungi of imperfect fungi. Minneapolis: Burgess Publishing Company, 1972. $241 \mathrm{p}$.

BARROCAS, E. N.; MACHADO, J. C.; ALVES, M. C.; CORRÊA, C. L. Desempenho de sementes de algodão submetidas à deficiência hídrica e presença de Colletotrichum gossypii var. cephalosporioides.
Bioscience Journal, Uberlândia, v. 30, n. 2, p. 421428, mar./apr. 2014. Available at: <http://www. seer.ufu.br/index.php/biosciencejournal/article/ viewFile/17993/13757>. Accessed at: 12 june 2015.

BRASIL. Ministério da Agricultura, Pecuária e Abastecimento. Manual de análise sanitária de sementes. Secretaria de defesa agropecuária. Brasília: Mapa/ACS, 2009. $200 \mathrm{p}$.

CARVALHO, J. C. B.; MACHADO, J. C.; VIEIRA, M. G. G. C. Crescimento micelial de Colletotrichum lindemuthianum em relação à restrição hídrica do substrato agarizado. Ciência Agrotecnológica, Lavras, v. 25, n. 4, p. 999-1005, 2001. Disponível em: <http://www.scielo.br/ scielo.php?script $=$ sci_nlinks\&ref $=000080 \& \mathrm{pid}=\mathrm{S} 0100-$ $5405201400020001000003 \& \operatorname{lng}=\mathrm{pt}>$. Acesso em: 29 nov. 2016.

CELANO, M. M.; MACHADO, J. C.; JACCOUD FILHO, D. S.; GUIMARÃES, R. M. Avaliação do potencial de uso da restrição hídrica em teste de sanidade de sementes de trigo visando à deteç̧ão de fungos. Revista Brasileira de Sementes, Londrina, v. 34, n. 4, p. 613-618, jul. 2012. Disponível em: <http://www.scielo.br/scielo. php?pid $=$ S0101-31222012000400012\&script $=$ sci arttext>. Acesso em: 16 apr. 2015.

DUNIWAY, J. M. Water relations of water molds. Annual Review of Phytopathology, Palo Alto, v. 17, n. 1, p. 431470, set. 1979. Available at: <http://www.annualreviews. org/doi/abs/10.1146/annurev.py.17.090179. 002243? journalCode=phyto $>$. Accessed at: 29 nov. 2016.

FARIAS, C. R. J.; DEL PONTE, E. M.; CORRÊA, C. L.; AFONSO, A. P.; PIEROBOM, C. R. Infecção de sementes de trigo com Bipolaris sorokiniana pela técnica de restrição hídrica. Tropical Plant Pathology, Brasília, v. 35 , n. 4, p.253-257, jul./ aug. 2010. Disponível 
em: $\quad<$ http://www.scielo.br/scielo.php?pid=S1982$56762010000400009 \&$ script $=$ sci arttext $>$. Acesso em: 18 apr. 2015.

FEDERAÇÃO DA AGRICULTURA DO ESTADO DO PARANÁ - FAEP. FAEP e MAPA esclarecem produtor sobre sementes para uso próprio. Paraná: FAEP, 2006. Disponível em: <http://www.faep.com.br/boletim/bi932/ bi932pag10.htm>. Acesso em: 8 dec. 2016.

FERREIRA, L. G. R. Fisiologia vegetal: relações hídricas. Fortaleza: Universidade Federal do Ceará, 1988. $137 \mathrm{p}$.

GARCIA JÚNIOR, D.; VECHIATO, M. H.; MENTEN, J. O. M. Comparação de métodos para a detecção de Fusarium graminearum em sementes de trigo (Triticum aestivum L.). Summa Phytopathologica, Botucatu, v. 34, n. 2, p. 164-167, apr./ jun. 2008. Disponível em: $\quad<$ http://www.scielo.br/scielo.php?pid=S0100$54052008000200010 \&$ script $=$ sci_arttext $>$. Acesso em: 16 apr. 2015.

GIROTTO, L.; ALVES, J. D.; DEUNER, S.; ALBUQUERQUE, A. C. S.; TOMAZONI, A. P. Tolerância à seca de genótipos de trigo utilizando agentes indutores de estresse no processo de seleção. Revista Ceres, Viçosa, v. 59, n. 2, p. 192-199, nov. 2012. Disponível em: $\quad<$ http://www.scielo.br/scielo.php?script=sci arttext\&pid=S0034-737X2012000200007>. Acesso em: 16 apr. 2015.

HEYDECKER, W.; HIGGINS, J.; TURNER, Y. J. Invigoration of seeds. Seed Science and Technology, Zurich, v. 3, n. 3-4, p. 701-709, aug. 1975.

MACHADO NETO, N. B.; CUSTÓDIO, C. C.; COSTA, P. R.; DONÁ, F. L. Deficiência hídrica induzida por diferentes agentes osmóticos na germinação e vigor de sementes de feijão. Revista Brasileira de Sementes, Londrina, v. 28, n. 1, p. 142-148, jun. 2006. Disponível em: $\quad<$ http://www.scielo.br/scielo.php? pid=S0101$31222006000100020 \&$ script $=$ sci_arttext $>$. Acesso em: 14 june 2015.

MACHADO, J. C.; OLIVEIRA, J. A.; VIEIRA, M. G. G. C.; ALVES, M. C. Inoculação artificial de sementes de soja por fungos, utilizando solução de manitol. Revista Brasileira de Sementes, Londrina, v. 23, n. 2, p. 95-101, oct. 2001b. Disponível em: <http://www.abrates.org.br/ revista/artigos/2001/v23n2/artigo13. pdf $>$. Acesso em: 12 apr. 2015.

. Uso da restrição hídrica na inoculação de fungos em sementes de algodoeiro (Gossypium hirsutum). Revista Brasileira de Sementes, Londrina, v. 26, n. 1, jan. 2004. Disponível em: $<$ http://www.scielo.br/ scielo. php?pid=s0101-31222004000100010\&script $=$ sci arttext>. Acesso em: 28 june 2015.
Uso da restrição hídrica na inoculação de fungos em sementes de milho. Revista Brasileira de Sementes, Londrina, v. 23, n. 2, p. 62-67, oct. 2001a. Disponível em: <http://www.abrates.org.br/revista/ artigos/2001/ v23n2/artigo12.pdf $>$. Acesso em: 12 apr. 2015.

MEHTA, Y. R. Manejo integrado de enfermidades del trigo. Santa Cruz de la Sierra: Imprenta Landivar S.R.L., 1993. $314 \mathrm{p}$.

MICHEL, B. E.; RADCLIFFE, D. A. Computer program relating solute potential to solution composition for five solutes. Agronomy Journal, Madison, v. 87, n. 1, p. 126130, dec. 1995. Available at: <https://dl.sciencesocieties. org/publications/aj/pdfs/87/1/AJ0870010126>. Accessed at: 5 june 2015.

OLIVEIRA, J. A. Efeito do tratamento fungicida em sementes e no controle de tombamento de plântulas de pepino (Cucumis sativus L.) e pimentão (Capsicum annuum L.). 1991. Dissertação (Mestrado em Fitossanidade) - Programa de Pós-Graduação em Agronomia/Fitopatologia, Universidade Federal de Lavras. Lavras.

PATEL, J. S.; MEINHARDT, S. W.; SIEROTZKI, H.; STAMMLER, G.; GUDMESTAD, N. C.; ADHIKARI, T. B. A two-step molecular detection method for Pyrenophora tritici-repentis isolates insensitive to QoI fungicides. Plant Disease, London, v. 95, n. 12, p. 15581564, jan. 2011. Available at: <http://apsjournals.apsnet. org/doi/pdf/10.1094/PDIS-05-11-0413>. Accessed at: 14 apr. 2015.

QUEIROGA, V. P.; BRUNO, R. L. A.; LIMA, M. M. A.; SANTOS, J. W. dos. Qualidade fisiológica de sementes de algodoeiro submetidas ao condicionamento mátrico e osmótico. Revista Ceres, Viçosa, MG, v. 58, n. 1, p. 56-61, feb. 2011. Disponível em: <http://www.scielo.br/scielo. php?pid=S0034-737X2011000100009\&script $=$ sci arttext>. Acesso em: 16 apr. 2015.

SANTANA, F. M.; CLEBSCH, C. C.; FRIESEN, T. L. Caracterização de raças de Pyrenophora tritici-repentis, agente etiológico da mancha amarela do trigo, no sul do Brasil. Passo Fundo: Embrapa Trigo, 2008. 13 p. (Boletim de Pesquisa e Desenvolvimento Online, 60). Disponível em: <http://ainfo.cnptia.embrapa.br/digital/ bitstream/CNPT-2010/40333/1/p-bp60.pdf > . Aecsso em: 15 apr. 2015.

SCHILDER, A. M. C.; BergSTROM, G. C. Seed transmition of Pyrenophora tritici-repentis, causal fungus of tan spot of wheat. European Journal of Plant Pathology, Dordrecht, v. 101, n. 1, p. 81-91, sept. 1995. Available at: <http://link.springer.com/ article/10.1007\%2FBF01876096>. Accessed at: 14 apr. 2015. 
SILVA, F. de A. S. E; AZEVEDO, C. A. V. de. Versão do programa computacional Assistat para o sistema operacional Windows. Revista Brasileira de Produtos Agroindustriais, Campina Grande, v. 4, n. 1, p. 71-78, 2002. Disponível em: <http://www.deag.ufcg.edu.br/ rbpa/rev41/Art410.pdf>. Acesso em: 5 feb. 2015.

SOUZA, M. V.; MACHADO, J. C.; PFENNING, L. H.; KAVASAKI, V. H.; ARAÚJO, D. V.; SILVA, A. A.; MARTINI NETO, A. Métodos de inoculação e efeito de Fusarium oxysporum f. sp. vasinfectum em sementes de algodoeiro. Tropical Plant Pathology, Brasília, v. 33, n. 1, p. 41-48, jan./ fev. 2008. Disponível em: $<$ http://www.scielo.br/scielo.php?script $=$ sci_arttext\&p $\mathrm{id}=\mathrm{S} 1982-56762008000100007>$. Acesso em: 15 feb. 2015 .
TAIZ, L.; ZEIGER, E. Fisiologia vegetal. 4. ed. Porto Alegre: Artmed, 2009. 848 p.

WEARING, A. H.; BURGESS, L. W. Water potential and the saprophyt growth of Fusarium roseum Graminearum. Soil Biology and Biochemistry, San Diego, v. 11, n. 6, p. 661-667, may 1979. Available at: $\quad<$ http://www.sciencedirect.com/science/article/ pii/0038071779900361>. Accessed at: 20 apr. 2015.

WIESE, M. V. Compendium of wheat diseases. $2^{\text {th }}$ ed. St. Paul: APS Press, 1987. 112 p. 